PSYCHIATRY IN THE PRACTICE OF MEDICINE By A. J. Enelow and $M$. Wexler. (Pp. viii + 355. 52s.) London: Oxford University Press. 1966.

A HANDBOOK OF SURGICAL DIATHERMY By J. P. Mitchell and G. N. Lumb. (Pp. 100; 106 figures. 37s. 6d.) Bristol: John Wright \& Sons. 1966.

les CéPhalées allergiques By J. Blamoutier and C. Denimal. (Pp. 112; 11 figures. F.24) Paris: Expansion Scientifique francaise. 1966.

STEREOTAXIC ATLAS OF THE FOREBRAIN OF THE GUINEA PIG By T. Luparello. (Pp. 80; 63 figures. DM 43.) Basel and New York: S. Karger AG. 1967.

THE DEVELOPMENT OF SEX DIFFERENCES Edited by E. E. Maccoby. (Pp. 351; illustrated. 60s.) London: Tavistock Publications. 1967.

eSSENTIELle HYPERTONIE. Klinik, Psychophysiologie und. psychopathologie By A. W. von Eiff, G. Kloska and PH. Quint. (Pp. xii + 232; 9 figures; 3 tables. DM 45, Stuttgart: Georg Thieme Verlag. 1967.

MADNESS AND CIVILISATION By M. Foucault. (Pp. xiv + 299. 35s.) London: Tavistock Publications. 1967.

IL PROBlema della coscienza in NeUROPSiCHIATRIA By R. Viziolo and Clelia Bietti. (Pp. 216; illustrated.) Pisa: Omnia Medica. 1966.

PADIATRISCHE NEUROCHIRURGIE Edited by J. Gerlach, H. P. Jensen, W. Koos and H. Kraus. (Pp. $x x+876$; 635 figures. DM 287.) Stuttgart: Georg Thieme Verlag. 1967.

SCHEMA DER SEGMENTALEN HAUTINNERVATION: DERMATOME By K. Hansen and $H$. Schliak. (50 tear-off standard charts for clinical use; size $81 \times 5 \frac{1}{2}$ ". DM 9.80) Stuttgart: Georg Thieme Verlag. 1967.

BeItrage SUR EKSTASE Bibliotheca Psychiatrica et Neurologica No. 134 Edited by Th. Spoerri. (Pp. iv + 207; 2 figures. 79s.) Basel: S. Karger. 1968.

ADVANCES IN OPTHALMOLOGY Vol. 19. Bibliotheca Opthalmologica No. 73 Edited by M. J. Roper-Hall, H. Sautter, and E. B. Streiff. (Pp. vi +221 ; 92 figures, 20 tables. 117s.) S. Karger: Basel. 1967.

A STEREOTAXIC ATLAS OF THE JAVA MONKEY BRAIN (Macaca irus) By Totada R. Shantha, Sohan L. Manocha, and G. H. Bourne. (Pp. iv +68 ; 64 figures. 69s.) S. Karger: Basel. 1968.

INDIVIDUALITY IN PAIN AND SUFFERING By Asenath Petrie. (Pp. xvii +153 ; 33 figures, 30 tables. 45s.) Chicago and London: University of Chicago Press. 1968.
STUDIES IN PSYCHIATRIC ART. Its Psychodynamics, Therapeutic Value, and Relationship to Modern Ar. By R. W. Pickford. (Pp. xix +340 ; illustrated $\$ 14.00$.) Springfield, Illinois: Charles C. Thomas. 19676

THE LOSS OF LOVED ONES. The Effects of a Death in the Family on Personality Development. Compiled and edited by D. M. Moriarty. (Pp. xvi $+203 ; 2$ figuresळ $\$ 8.50$.) Springfield, Illinois: Charles C. Thomas. $1967 \overline{\mathrm{d}}$

ECHOENZEPHALOGRAPHIE By $\mathrm{H}$. W. Pia and C.-L Geletneky. (Pp. viii $+168 ; 128$ figures, 20 tables DM 59.) Stuttgart: Georg Thieme Verlag. 1967.

ANGIOGRAPHIE DES HIRNKREISLAUFS By K. Decker an H. Backmund. (Pp. viii + 76; illustrated. DM 44. Stuttgart: Georg Thieme Verlag. 1967.

HYDRODYNAMIK, ELEKTROLYT- UND SAURE-BASEN-HAUSHALT IM LIQUOR UND NERVENSYSTEM. Symposium vOMP 27. 2.-1.3. 1967 der Neurologischen Klinik desKrankenhauses Nordwest, Frankfurtam Mein. Edite by G. Kienle. (Pp. xi +268 ; 168 figures, 46 tables DM 52.40.) Stuttgart: Georg Thieme Verlag. 1967.

\section{PROLONGED COMA AND RECOVERY} The Editor has received the following letter from Fo잉 fessor $W . H$. Sweet, Professor of Surgery at Massactusetts General Hospital and chief of the neurosurgitat service there. It covers an important subject and he hoke that readers will try to help Professor Sweet's invegtie gations.

24 January, 198

Dear Sir-The ability of physicians to maintain life $\$$ very long periods in the unconscious patient raises the question as to how long such skills should be deployed As physicians we are eager to promote the recovery of everyone who can do so. In order to deprive no one of his chances on this score it is relevant to know the longest periods of coma which have been followed b useful survival.

A committee of the Massachusetts General Hospitaf is studying our own records and the world literature to determine pertinent features in all patients who, despite coma for over five weeks, have made a useful recoverye We think it is vital not to overlook any well-documented. patient in this category. We should be grateful if any reader of this journal would draw our attention to any case published under a title which is not indicative op survival after prolonged coma. We are also eager tợ. receive accounts of such cases as yet unreported. A publication incorporating our own and others' data is planned.-I am, etc.,

WILLIAM H. SWEET $\stackrel{\circ}{?}$

Chairman, Committee on Management of the Unconscious Patien Massachusetts General Hospital, Boston, Massachusetts 0211年 U.S.A. 